\title{
TOURISM - ECONOMIC GROWTH NEXUS. THE CASE OF ROMANIA
}

\author{
Alina BADULESCU ${ }^{\circledR 1}$, Daniel BADULESCU ${ }^{(1 D}{ }^{*}$, \\ Ramona SIMUT ${ }^{10}{ }^{3}$, Simona DZITAC (D) 4 \\ ${ }^{1,2,3}$ Department of Economics and Business, Faculty of Economic Sciences, \\ University of Oradea, Oradea, Romania \\ ${ }^{4}$ Department of Energy Engineering, Faculty of Energy Engineering and Industrial Management, \\ University of Oradea, Oradea, Romania
}

Received 20 September 2019; accepted 23 February 2020

\begin{abstract}
The development of tourism is usually associated, in positive terms, with economic development, foreign currency inflows, employment opportunities, infrastructure improvements, sustainable development and poverty alleviation. However, the nature of the tourism-growth relationship is still a matter of academic debate, and, perhaps, an expression of the inconsistencies and contradictions of public policies designed to support this industry. Researchers and practitioners have not yet come to an agreement on a number of fundamental questions: does tourism stimulate economic growth or the converse, and whether the causality, if it does exist, is uni or bidirectional, is constant or can change its direction in the medium - or long run. The present paper investigates the relationship between Gross Domestic Product (GDP) per capita and international tourism in Romania, over the 1995-2016 period. Our results show that the causal effect of the GDP on the international tourist arrivals and on the international tourism receipts is significant in the long run in Romania. In the short-run, we find a unidirectional causal relationship from the international tourism receipts to GDP, and a bidirectional causal relationship between GDP and the number of international tourist arrivals.
\end{abstract}

Keywords: international tourism, economic growth, TLGH, GTLH Romania, Johansen cointegration test, Granger causality.

JEL Classification: Z32; F43; L83; R11.

\section{Introduction}

According to the World Tourism Organization (2018), the growth of international exchanges, the promotion of new destinations and the massive investments in tourism in the last decades contributed to the transformation of this industry into a key factor of development, job creation and business enhancer, infrastructure developments and an increase in export

*Corresponding author. E-mail: dbadulescu@uoradea.ro

This is an Open Access article distributed under the terms of the Creative Commons Attribution License (http://creativecommons. org/licenses/by/4.0/), which permits unrestricted use, distribution, and reproduction in any medium, provided the original author and source are credited. 
incomes. The share of tourism in the global economic activity is estimated at ca. $10 \%$ of the world's GDP, 7\% of global trade and almost 10\% of total jobs (World Tourism Organization [WTO], 2019). In the last decade, the growth rate of worldwide international tourist arrivals (overnight visitors) is almost double that of the global economy. These figures could be even greater if we also consider the indirect effects of tourism development to other economic sectors. Thus, according to the World Travel \& Tourism Council [WTTC], travel and tourism is one of the largest sectors, covering $10.4 \%$ of world GDP (WTTC, 2019), and the benefits are particularly significant in developing countries. International tourism generates income growth, increases competition and efficiency among local firms, by connecting them to the international network of tour-operators, and, not least, by creating economies of scale in small firms (Balaguer \& Cantavella-Jorda, 2002).

The development of tourism industry has become a significant issue in numerous countries, both theoretically and practically, by designing and adopting various policies and stimuli. Thus, tourism has been positively associated to economic development, monetary gains, generation of employment opportunities, infrastructure improvements, sustainable development and the reduction of poverty, but also associated to more sensitive and ambivalent topics, such as social and environmental impact, cultural values etc. International tourism incomes can be assimilated to an alternative form of export, both through the direct revenues of tourism services, as well as by stimulating the consumption of local products (in other words, stimulating the export of said products). Tourism improves the development opportunities of small, local businesses (Watkins et al., 2018). In other words, tourism is a source of revenue based on in situ consumption (Cortés-Jiménez et al., 2009). Implicitly, this type of consumption isn't limited through a development of tourism in a given (social, geographical) context, but to other sectors of the national or local economy, through spill-overs and externalities (Balaguer \& Cantavella-Jorda, 2002). Finally, tourism contributes to generating investments flows and financial resources for local and central public administrations, and thus contributes to solving social issues by improving employment opportunities and the standard of living, as well as by harmonising the rate of local and regional growth (Sehleanu, 2019). The interest in analysing tourism with respect to economic growth and government policies also stems from the fact that tourism (as an export supplier) can be a complementary channel consolidating economic growth (Lanza \& Pigliaru, 2000), being taken into account in policies, strategies and promotional actions by governments (Cortés-Jiménez et al., 2009). However, there are researchers considering that the role of tourism as a substitute of imports and a source of monetary gains should not be exaggerated, due to its extreme sensitivity to external competition, high prices' elasticity, unforeseen external events (disasters, epidemics, and terrorism), fashion and seasonal changes (Mathieson \& Wall, 1982; Bac \& Aksoz, 2017).

All in all, investigating the direction of the complex relationship between tourism and economic growth is essential in providing evidence to be employed in shaping economic policies regarding the development of tourism industry.

This study focuses on the case of Romania, an emerging Eastern European economy with a particular situation of tourism ressources versus tourism industry contribution to GDP. The expectations of transitional and emerging countries regarding tourism as a driver of economic growth, but also as beneficiary of reforms and political and economic trans- 
formation (especially in Central and Eastern Europe) are considerable and have a history of over 20 years. Romania is an epitome of this situation: endowed with a significant touristic heritage, it experienced a decline of internal tourism in the first decades after 1990, and an increased dynamism of outbound flows. Slowly, these tendencies were counterbalanced by the growth and continuous adaptation of accommodation capacity, a revival of inbound flow, a balancing of touristic inflows and outflows, and a slow but steady growth of the share of tourism in the GDP. This begs the question, to what extent is this rebound of tourism due to Romania's economic growth in the last decade and to what extent has tourism contributed to said growth. We consider that the answers are relevant not only to this specific case, but also in regional (and wider) terms, considering the necessity of intelligent and efficient policies aiming to exploit touristic potential and harmonize the evolution of the tourism sector to the overall development of the world's regions and states.

Therefore, this study investigates the nexus between international tourism (expressed by both international tourist arrivals and international tourism receipts) and economic growth (measured by GDP per capita) for the case of Romania. We examine all the directions of this nexus, i.e. the tourism-led economic growth hypothesis (TLGH) and the economy-driven tourism growth hypothesis (EDTGH), by using the Johansen cointegration test and Granger causality for the 1995-2016 period of time. The (remaining part of the) paper is organized as follows. In Section 1 we present a literature review on the hypotheses of the tourism-economic growth relationship on an international and Romanian level. In Section 2 we present the data and methodology, in Section 3 the calculations and in Section 4 we discuss the results. In the last section we present a brief conclusion of the results obtained in this study, policy recommendations and the limitations of the study.

\section{Literature review}

\subsection{Hypotheses on tourism - economic growth nexus: international overview}

While the existence of a tourism-growth relationship is accepted and empirically proven in numerous cases and regional contexts, there is yet no consensus on its fundamental aspects, e.g. its direction, strength and time-dependence. In other words, does tourism stimulate economic growth or is the converse true? Is there a causality relationship between the two, and, provided that it exists, is it uni- or bidirectional, and can it change its direction on the medium or long-term? Empirical literature on the causal relationship between tourism and economic growth groups these hypotheses in four main categories.

The first is the tourism-led growth hypothesis - TLGH (or TLEG), which states that tourism is a major driver for economic growth. The second is the growth-led tourism hypothesis - GLTH (or economic driven tourism growth hypothesis - EDTG), which considers that economic growth contributes to the development of the tourism sector. The third considers a bidirectional relationship between them (bidirectional causality hypothesis - BC). Finally, the last view (the fourth) is that of neutrality (no causality hypothesis - NC).

TLGH is by far the most supported model (as shown by a varied and significant body of economic literature), a model which is based on variate model and techniques (cross section and panel data, VAR or VECM, ARDL, ARCH, GARCH, input-output analysis). 
The TLGH hypothesis is demonstrated by Balaguer and Cantavella-Jorda (2002) in the case of Spain between 1975-1997, who include in the model the evolution of real GDP, international tourism receipts, and the effective real exchange rate; Durbarry (2004) in the case of Mauritius for the relationship between real exports and real GDP between 1952 and 1999; Hye and Khan (2013) in the case of Pakistan, who identify the relationship as most significant in the long run; Kibara et al. (2012) for Kenya, both long and short term. Arslanturk and Atan (2012) for Turkey, Tang and Tan (2015) for Malaysia, and Mishra et al. (2011) for India, support a long-term one-way causality between tourism activities and economic growth, while Akinboade and Braimoh (2010) for South Africa additionally support a short-term causality. Jalil et al. (2013) for Pakistan between 1972-2011, and Brida et al. (2008) for Chile, also found out that economic development in the above-mentioned nations was supported by the development of international tourism. Sanchez Carrera et al. (2008) for 1980-2007 in Mexico, and Bento (2016) for 1995-2015 in Portugal, confirm the TLGH hypothesis, i.e. that tourism development precedes economic growth. In the case of Greece, both Eeckels (2012) for 1976-2004, and Bayramoğlu and Arı (2015) for 1980-2013, found unidirectional causality, i.e. from the spending of foreign tourists to economic growth. Other studies confirm TLGH for groups of countries, such as Schubert et al. (2011) on small island economies dependent on tourism between 1970 to 2008, Caglayan et al. (2012) who found a unidirectional causality from tourism to economic growth in the case of 135 East and South Asian economies, and a unidirectional causality but this time from economic growth to tourism in the case of Latin America and Caribbean economies (Gwenhure \& Odhiambo, 2017), or Fahimi et al. (2018) on several small states over the period 1995-2015. Lee and Chang (2008), analysing OECD and non-OECD countries for the interval 1990-2002, state that TLGH holds only for OECD economies. Sequeira and Nunes (2008), analysing a few groups of countries (including small and developing countries), from 1980 to 2002, discover a unidirectional tourism-to-growth relationship, but weaker in small and developing countries. Cárdenas-García et al. (2015) classify 144 countries into 2 groups, based on unequal socioeconomic development, and discover that tourism foster economic growth mostly in developed economies. In economies with a lower level of economic development, while tourism did positively influence economic growth, it did not ensure the countries' or local economies' prosperity.

A second perspective, the GLTH claims that economic growth determines the development of tourism. By various methods and tests (bivariate model, VAR and Granger causality tests, Toda-Yamamoto causality or ARDL bounds testing), the relationship is confirmed by Oh (2005) for 1975-2001 in South Korea, by Katircioglu (2009a) for Cyprus, and by Payne and Mervar (2010) in the case of Croatia (2000-2008).

The third perspective is grounded on a series of studies which highlight, at least for a certain number of countries and time-frames, a bidirectional influence of tourism and economic growth. Thus, analysing international tourism in Greece for 1960-2000, Dritsakis (2004), by Johansen cointegration and error correction, supports a bidirectional influence between international tourism and growth. By similar methods and tests, the same relationships are identified in Turkey for 1980-2004 (Demiroz \& Ongan, 2005), Taiwan between 1959 and 2003 (Lee \& Chien, 2008) and 1956 to 2002 (Kim et al., 2006), Ecuador (Rivera, 2017), Italy 
and Spain from 1954 to 2000 (Cortés-Jiménez et al., 2009). In addition to these studies, which refer to a single or at most two countries, a number of studies identify a bidirectional relationship between tourism and growth for groups of countries or regions, such as Tugcu (2014) for Mediterranean countries between 1988 and 2011, Apergis and Payne (2012) for nine Caribbean countries, Dogru and Bulut (2018), for seven European countries, Chou (2013) for 10 European emerging economies between 1988-2011, or Lee and Chang (2008) for several non-OECD economies.

The last hypothesis, that of neutrality, claims the non-existence of causality between tourism and growth, as encountered in the works of Brida et al. (2011) for Latin America, Katircioglu (2009b) (insignificant or unconvincing causal relation) and Ozturk and Acaravci (2009) both for Turkey, Kasimati (2011) for Greece, or Tang and Jang (2009) for US.

\subsection{The relationship tourism - economic growth in Romania}

While Romanian tourism is of substantial interest to Romanian (and occasionally international) researchers, systematic analyses of the relationship between tourism and economic growth are relatively few. In the following paragraphs we will summarise the most important contributions to the topic.

Surugiu et al. (2009) analysed tourism's importance and contribution to the Romanian economy between 1990 and 2008, a period characterised by a decline in tourism activity. Using Input - Output analysis, the authors found a relatively low potential for economic operators in tourism to increase the supplies for sectors using the tourism product in their production (Surugiu et al., 2009).

In another study, C. Surugiu and M.-R. Surugiu (2013) found that TLGH holds for Romania (C. Surugiu \& M.-R. Surugiu, 2013). In other words, the authors highlight the fact that tourism exerts a significant impact on growth and, thus, the demand for internal tourism should be encouraged, while also monitoring the noticeable increase in the outbound Romanian tourism. Promoting national tourism destinations, improving the infrastructure and diversifying recreational facilities must take place concurrent with increasing awareness of the general benefits resulting from supporting internal tourism.

Finally, C. Surugiu and M.-R. Surugiu (2015), reinterpret the results of Zaman et al. (2010), by applying and developing the Generation of Regional Input - Output Model on a specific region of Romania. The authors insist on the significance of the obtained results, which need to be extended to the other regions of Romania, in order to provide theoretical arguments for policies supporting tourism, as well as to better value the natural and cultural heritage of tourism (Zaman et al., 2010).

Without supporting or explicitly mentioning any of the above-mentioned theories (TLGH, GTLH), other studies and articles highlight the potential and good growth rates of tourism in Romania, while also mentioning the precarious state of the infrastructure, the lack of vision of sectorial or macroeconomic policies, and the overall state of economic development as hindrances in fully capitalising the potential of this sector (Mazilu et al., 2018), as well as the imperative of Romania not being considered an interesting, yet peripheral destination of international tourism (Postelnicu \& Dabija, 2018). 
Other figures and opinions on the tourism contribution to the national economy are provided by Romanian country reports issued by WTTC, the most recent being Travel \& Tourism Economic Impact 2018. Romania (WTTC, 2018). While not explicitly stated, WTTC supports (through promoted indicators - direct and indirect contribution to GDP, employment, visitors, exports and investments) the TLGH hypothesis, i.e. travel and tourism are a significant economic activity in most countries, with direct, indirect and induced economic effects (WTTC, 2012). According to these studies, in 2017, in Romania, the tourism direct contribution to GDP was USD 3,024.1 million (1.4\% of total GDP), with prognosis to rise by $4.6 \%$ in 2018 , and to $2.1 \%$ per annum, from $2018-2028$, to $1.5 \%$ of total GDP in 2028 . The total contribution of travel \& tourism to GDP was USD11, 185.7 million (5.3\% of GDP in 2017), and is forecast to rise by $5.5 \%$ in 2018-2028. Regarding the relative importance of the overall contribution of travel \& tourism sector to GDP, out of 185 countries, Romania (2017) is ranked the $59^{\text {th }}$ (in absolute terms), and the $150^{\text {th }}$ (in relative size), which could improve in the next decade to the $44^{\text {th }}$ place (WTTC, 2018).

Moreover, the tourism-growth relationship for Romania is encountered in other panel analysis studies, alongside other countries (grouped by various criteria: regional, level of development etc.). The framing of Romanian tourism into one of the four theories according to each paper is presented in Table 1.

In conclusion, based on empirical studies listed above, different results have been obtained for Romania, such as: a majority of studies which describe a unidirectional causality support the TLGH hypothesis rather than the EGTH. However, a few studies show a bidirectional causality, but only in the short term.

Table 1. Empirical studies on the tourism-growth causal relationship in Romania (source: own elaboration)

\begin{tabular}{|l|l|l|l|}
\hline \multicolumn{1}{|c|}{$\begin{array}{c}\text { Author/s and } \\
\text { publication's year }\end{array}$} & \multicolumn{1}{|c|}{ Method } & \multicolumn{1}{c|}{ Conclusion } & \multicolumn{1}{c|}{ Obs } \\
\hline $\begin{array}{l}\text { C. Surugiu and } \\
\text { M.-S. Surugiu (2013) }\end{array}$ & $\begin{array}{l}\text { Vector error } \\
\text { correction model } \\
\text { (VECM) }\end{array}$ & $\begin{array}{l}\text { Tourism-led growth } \\
\text { hypothesis was confirmed } \\
\text { for domestic tourism }\end{array}$ & $\begin{array}{l}\text { Romania 1988-2009 } \\
\text { Variables: GDP growth, } \\
\text { exchange rate and tourism } \\
\text { consumption (domestic } \\
\text { and international tourism) }\end{array}$ \\
\hline $\begin{array}{l}\text { C. Surugiu, Frent, } \\
\text { and M. Surugiu } \\
\text { (2009) }\end{array}$ & $\begin{array}{l}\text { Input-Output } \\
\text { model (IO } \\
\text { model) }\end{array}$ & $\begin{array}{l}\text { Very low output, income, } \\
\text { value added, and } \\
\text { employment multipliers }\end{array}$ & $\begin{array}{l}\text { Romania, 1990-2008 } \\
\text { Variables: tourism } \\
\text { demand, output, income, } \\
\text { employment and value } \\
\text { added }\end{array}$ \\
\hline $\begin{array}{l}\text { Zaman, Vasile, M.-R. } \\
\text { Surugiu, and } \\
\text { C. Surugiu (2010) }\end{array}$ & $\begin{array}{l}\text { Input-Output } \\
\text { model (IO } \\
\text { model) }\end{array}$ & $\begin{array}{l}\text { Decreasing share of tourism } \\
\text { in overall national output. } \\
\text { Tourism registers small } \\
\text { multipliers }\end{array}$ & $\begin{array}{l}\text { Romania, 2000-2008 } \\
\text { Variables: tourism arrivals, } \\
\text { output, wage earnings, } \\
\text { employees and value } \\
\text { added }\end{array}$ \\
\hline $\begin{array}{l}\text { C. Surugiu and } \\
\text { M. R. Surugiu (2015) }\end{array}$ & $\begin{array}{l}\text { A regional Input- } \\
\text { Output analysis }\end{array}$ & $\begin{array}{l}\text { Lower backward or forward } \\
\text { regional multipliers for } \\
\text { tourism compared to other } \\
\text { sectors }\end{array}$ & $\begin{array}{l}\text { Romania, 2008, Variables: } \\
\text { tourism demand, output, } \\
\text { gross value added }\end{array}$ \\
\hline
\end{tabular}


Continue of Table 1

\begin{tabular}{|c|c|c|c|}
\hline $\begin{array}{c}\text { Author/s and } \\
\text { publication's year }\end{array}$ & Method & Conclusion & Obs \\
\hline $\begin{array}{l}\text { WTTC (Country } \\
\text { Report Romania) } \\
\text { (2018) }\end{array}$ & $\begin{array}{l}\text { Sum of (1) direct, } \\
\text { (2) indirect } \\
\text { (inter-industry } \\
\text { linkages), and } \\
\text { (3) induced } \\
\text { (incomes earned } \\
\text { directly and } \\
\text { indirectly in the } \\
\text { local economy) } \\
\text { impacts }\end{array}$ & $\begin{array}{l}\text { Contribution of Travel } \\
\text { \& Tourism sectors to } \\
\text { Romanian economy (2017) } \\
\text { was: } \\
-5.3 \% \text { in total GDP; } \\
-6.3 \% \text { in total } \\
\text { employment; } \\
-8.1 \% \text { in total investment }\end{array}$ & Romania, 2017-2018 \\
\hline $\begin{array}{l}\text { Biji, Lilea, Vătui, and } \\
\text { Roşca (2015) }\end{array}$ & $\begin{array}{l}\text { Multi-criteria } \\
\text { analysis by the } \\
\text { method of ranks } \\
\text { and the method } \\
\text { of relative } \\
\text { distance; } \\
\text { The linear trend } \\
\text { function; } \\
\text { The second- } \\
\text { degree parabola. }\end{array}$ & $\begin{array}{l}\text { For the market share of } \\
\text { tourist demand time series } \\
\text { (number of nights spent in } \\
\text { the main tourism region/ } \\
\text { total country), it is observed } \\
\text { that both functions indicate } \\
\text { increasing trends for five } \\
\text { regions, decreasing trends } \\
\text { for } 11 \text { regions, and opposite } \\
\text { tendencies, with increasing } \\
\text { linear function in } 8 \text { regions } \\
\text { and with increasing second } \\
\text { degree parabola in } 3 \text { regions }\end{array}$ & $\begin{array}{l}\text { EU Members State } \\
\text { (countries and regions), } \\
\text { including Romania, } \\
\text { 1998-2011 }\end{array}$ \\
\hline $\begin{array}{l}\text { Badulescu, Simut, } \\
\text { and Badulescu } \\
(2018)\end{array}$ & $\begin{array}{l}\text { Autoregressive } \\
\text { Distributed Lag } \\
\text { (ARDL) model }\end{array}$ & $\begin{array}{l}\text { Between tourism } \\
\text { (international arrivals, and, } \\
\text { respectively, international } \\
\text { receipts) and GDP, exist: } \\
\text { - a short-run bidirectional } \\
\text { relationship; } \\
\text { - a long-run } \\
\text { unidirectional } \\
\text { relationship }\end{array}$ & $\begin{array}{l}\text { Central and Eastern } \\
\text { European economies, } \\
\text { including Romania, } \\
\text { 1995-2015 } \\
\text { Variables: GDP per capita } \\
\text { and international tourism }\end{array}$ \\
\hline $\begin{array}{l}\text { Cárdenas-García, } \\
\text { Sánchez-Rivero, and } \\
\text { Pulido-Fernández } \\
(2015)\end{array}$ & \begin{tabular}{|l|} 
Structural \\
Equation Model \\
(SEM)
\end{tabular} & $\begin{array}{l}\text { TLGH validated for } \\
\text { Romania }\end{array}$ & $\begin{array}{l}144 \text { countries, including } \\
\text { Romania, 1991-2010 } \\
\text { Variables: multiple }\end{array}$ \\
\hline $\begin{array}{l}\text { Škrabić Perić and } \\
\text { Vidović (2017) }\end{array}$ & $\begin{array}{l}\text { Heterogeneous } \\
\text { Panel Granger } \\
\text { causality test }\end{array}$ & $\begin{array}{l}\text { Bidirectional Granger } \\
\text { causality GDP - tourism } \\
\text { for } 5 \text { European emerging } \\
\text { economies }\end{array}$ & $\begin{array}{l}11 \text { economies, including } \\
\text { Romania, 1995-2013 } \\
\text { Variables: GDP and } \\
\text { international tourism } \\
\text { receipts }\end{array}$ \\
\hline Chou (2013) & $\begin{array}{l}\text { Panel causality } \\
\text { analysis }\end{array}$ & $\begin{array}{l}\text { Tourism-growth } \\
\text { relationship significant, but } \\
\text { no significant relationship } \\
\text { between the per capita } \\
\text { real GDP and domestic } \\
\text { tourism spending (neutral } \\
\text { relationships) in Romania, } \\
\text { Bulgaria and Slovenia }\end{array}$ & $\begin{array}{l}10 \text { transition countries, } \\
\text { including Romania, } \\
\text { 1988-2011 } \\
\text { Variables: GDP per capita } \\
\text { and domestic tourism } \\
\text { spending }\end{array}$ \\
\hline
\end{tabular}


End of Table 1

\begin{tabular}{|l|l|l|l|}
\hline \multicolumn{1}{|c|}{$\begin{array}{c}\text { Author/s and } \\
\text { publication's year }\end{array}$} & \multicolumn{1}{|c|}{ Method } & \multicolumn{1}{c|}{ Conclusion } & \multicolumn{1}{c|}{ Obs } \\
\hline $\begin{array}{l}\text { Martins, Gan, and } \\
\text { Ferreira-Lopes } \\
\text { (2017) }\end{array}$ & $\begin{array}{l}\text { Panel data } \\
\text { Poisson } \\
\text { regression model } \\
\text { and } \\
\text { Standard methods } \\
\text { for panel data } \\
\text { with real valued } \\
\text { dependent data }\end{array}$ & $\begin{array}{l}\text { Real expenditures per } \\
\text { arrivals has a quite lower } \\
\text { effects on GDP }\end{array}$ & $\begin{array}{l}\text { 218 countries, including } \\
\text { Romania, 1995-2012 } \\
\text { Variables: World GDP per } \\
\text { capita, nominal exchange } \\
\text { rate, relative prices, and } \\
\text { tourism demand (inbound } \\
\text { number of visitors and } \\
\text { tourism expenditures) }\end{array}$ \\
\hline $\begin{array}{l}\text { Sánchez-Rivero, } \\
\text { Pulido-Fernández, } \\
\text { and Cárdenas-García } \\
\text { (2013) }\end{array}$ & $\begin{array}{l}\text { Canonical } \\
\text { correspondence } \\
\text { analysis }\end{array}$ & $\begin{array}{l}\text { Inconclusive results - } \\
\text { Country with medium } \\
\text { economic growth and } \\
\text { medium to weak tourism } \\
\text { growth }\end{array}$ & $\begin{array}{l}\text { 177 countries, including } \\
\text { Romania, 1999-2008 } \\
\text { Variables: the growth of } \\
\text { tourism (6 indicators) and } \\
\text { economic development } \\
\text { (8 indicators) }\end{array}$ \\
\hline $\begin{array}{l}\text { Arezki, Cherif, and } \\
\text { Piotrowski (2009) }\end{array}$ & $\begin{array}{l}\text { Instrumental } \\
\text { variables } \\
\text { techniques (IV) }\end{array}$ & $\begin{array}{l}\text { Positive relationship } \\
\text { between tourism receipts } \\
\text { and growth (however, } \\
\text { the impact of tourism on } \\
\text { economic growth should } \\
\text { not be overestimated) }\end{array}$ & $\begin{array}{l}\text { 127 countries, including } \\
\text { Romania, 1980-2002 } \\
\text { Variables: GDP per capita } \\
\text { and tourism receipts }\end{array}$ \\
\hline
\end{tabular}

\section{Data and methodology}

In order to investigate the presence of the relationship between the Romanian GDP per capita (constant 2010 US\$) (GDP) and international tourism in Romania, measured by the number of arrivals (ARIV), and also the presence of a relationship between GDP per capita (in constant 2010 US\$) (GDP) and international tourism measured by the international tourism receipts (expressed in current US\$) (REC), this study employs the Johansen cointegration test and Granger causality. We used data provided by The World Bank database (2017). Given the limited availability and accessibility of the data, this study refers to the period 1995-2016. Table 2 presents the descriptive statistics for the dataset.

Table 2. Descriptive statistics (source: World Development Indicators (The World Bank, 2017))

\begin{tabular}{|l|c|c|c|}
\hline \multirow{2}{*}{} & \multicolumn{3}{|c|}{ Variables } \\
\cline { 2 - 4 } & GDP & ARIV & REC \\
\hline Minimum & 4779.7 & 4794000 & 306000000 \\
\hline Maximum & 10065.5 & 10223000 & 2630000000 \\
\hline Mean & 7048.64 & 6733682 & 1290000000 \\
\hline Median & 7121.6 & 6318500 & 1480000000 \\
\hline Std. Deviation & 1816.72 & 1642634 & 789000000 \\
\hline Skewness & 0.0377 & 0.4658 & 0.0571 \\
\hline Kurtosis & 1.4823 & 2.0186 & 1.3872 \\
\hline
\end{tabular}


According the descriptive statistics, all the variables are positively skewed and have a small kurtosis. Natural logarithms are used to transform the variables to ease the interpretation of the parameters and to avoid any problems of heteroscedasticity.

To test the long-run relationship between time-series variables, during the last two decades, a variety of econometric methods have been used. Although the econometric analysis of the time series starts from the assumption that the data in the observed time series have the stationary property, most economic time series do not satisfy the stationary conditions due to the many changes in the business environment. Thus, aspects regarding the importance, the consequences and the modalities of testing and realization of stationary assumptions become very important in the analysis of time series. Therefore, in order to test the relationship and the causality between the selected variables, firstly we examine the stationarity of all the variables. The next step is to test for cointegration in order to determine if the long-run equilibrium relationship between the selected variables exist or not, and the third step is to test the causality in order to find the type and the direction of the relationship.

Starting from these variables, i.e. GDP, ARIV and REC, we have stated and tested the following three hypotheses:

H1: For Romania, there is a long-run equilibrium that characterizes the relationship between tourism and economic growth.

H2: For Romania, there is a unidirectional relationship between international tourism and GDP: tourism-led economic growth hypothesis (TLGH) or the economy-driven tourism growth hypothesis (EDTGH).

H3: For Romania, there is a bidirectional relationship between economic growth and tourism.

\section{Calculation}

The analysis starts by investigating the stationarity or unit root test of the variables number of international tourist arrivals (ARIV), international tourism receipts (REC) and GDP per capita (GDP), see Table 3. We use the most common test, the Augmented Dickey Fuller test (see Dickey \& Fuller, 1979).

The unit root test results (ADF test) indicates that the null hypothesis is rejected at the $5 \%$ significance level after the first difference for ARIV variable and REC variable, while for GDP the null hypothesis is rejected at the $10 \%$ significance level after the first difference. Thus, it can be concluded that all variables have a unit root. Because the series are stationary at the first difference, these are integrated of order one, I(1). If the series of data are non-stationary at the level, they can be cointegrated, i.e. there is at least one linear combination between them that is stationary. Because the variables have the same order of integration I(1), the condition to be cointegrated is respected.

Johansen (1988) and Johansen and Juselius (1990) derived a procedure, maximum likelihood, that overcame the limitation of univariate cointegration (Johansen \& Juselius, 1990). In order to examine the existence of a cointegration between the selected variables, the methodology we use to estimate the model parameters is that proposed by Johansen (1991) and Johansen \& Juselius (1990), according to which the null hypothesis of non-cointegration will be tested. 
Table 3. Unit root test results (ADF test) (source: own calculations using Eviews 9)

\begin{tabular}{|c|c|c|c|c|}
\hline \multirow{2}{*}{\multicolumn{2}{|c|}{$\begin{array}{l}\mathrm{H}_{0} \text { : the series has a unit root } \\
\mathrm{H}_{1} \text { : the series is stationary }\end{array}$}} & \multicolumn{3}{|c|}{ Log values } \\
\hline & & \multirow{2}{*}{$\begin{array}{c}\text { LGDP } \\
3.597958(0.9996)\end{array}$} & \multirow{2}{*}{$\begin{array}{c}\text { LARIV } \\
1.397137(0.9542)\end{array}$} & \multirow{2}{*}{$\begin{array}{c}\text { LREC } \\
0.906403(0.8959)\end{array}$} \\
\hline \multirow{3}{*}{$\begin{array}{l}\text { ADF } \\
\text { (level) }\end{array}$} & None & & & \\
\hline & Intercept & $0.077361(0.9559)$ & $-0.105441(0.9367)$ & $-0.561286(0.8596)$ \\
\hline & Trend \& intercept & $-1.654713(0.7350)$ & $-2.805906(0.2104)$ & $-1.895031(0.6213)$ \\
\hline \multirow{3}{*}{$\begin{array}{l}\text { ADF } \\
\left(1^{\text {st }} \text { diff }\right)\end{array}$} & None & $-2.088676(0.0381)$ & $-3.650701(0.0010)$ & $-3.262762(0.0025)$ \\
\hline & Intercept & $-2.828529(0.0721)$ & $-3.950526(0.0074)$ & $-3.298809(0.0288)$ \\
\hline & Trend \& intercept & $-2.824689(0.0812)$ & $-3.967131(0.0280)$ & $-3.221693(0.1084)$ \\
\hline \multicolumn{2}{|c|}{ The order of integration } & $\mathrm{I}(1)$ & $\mathrm{I}(1)$ & $\mathrm{I}(1)$ \\
\hline
\end{tabular}

Note: p-value are in () and the optimal lag length is determined based on Akaike, Schwarz and HannanQuinn info Criterion.

To determine the number of cointegration relationships we can use the following two types of LR (likelihood ratio) tests, namely the Trace test $\left(\mathrm{LR}_{\max }\right)$ and the Maximum Eigenvalue test (Johansen \& Juselius, 1990; MacKinnon et al., 1999; Enders, 2014; Andrei \& Bourbonnais, 2017). In the case of the Trace test, the null hypothesis is that of the non-existence of a cointegration relationship between variables. This is accepted when the statistic value is less than the critical one (statistic $<\lambda$ critical, for $1 \%$ and $5 \%$ significance level). The Trace statistic is:

$$
\text { Trace }=-T \sum_{i=r+1}^{k} \log \left(1-\hat{\lambda}_{r+1}\right) \text {. }
$$

In the case of Maximum Eigenvalue test we have:

$$
\lambda_{\max }(r, r+1)=-T \log \left(1-\hat{\lambda}_{r+1}\right) .
$$

The null hypothesis is $\mathrm{H}_{0}: r$ cointegration relationship, while the alternative one is $\mathrm{H}_{1}: r+1$ cointegration relationship, for $r=0,1, \ldots, k-1$.

The critical values are determined by several authors (Johansen \& Juselius 1990; MacKinnon et al., 1999), and differ as the series have a deterministic constant and/or trend, respectively the cointegration equations contain a constant and/or a deterministic tendency.

Table 4. Cointegration test results (source: own calculations using Eviews 9)

\begin{tabular}{|c|l|l|c|c|c|c|}
\hline \multirow{2}{*}{ Variables } & \multicolumn{2}{|c|}{$\begin{array}{c}\text { Hypothesized } \\
\text { No. of CE(s) }\end{array}$} & \multirow{2}{*}{ Trace statistic } & \multirow{2}{*}{ Max-Eigen statistic } & \multicolumn{2}{c|}{ Critical Value (5\%) } \\
\cline { 6 - 7 } & & & & Trace & Max-Eigen \\
\hline \multirow{2}{*}{ LGDP/LARIV } & None & $\mathrm{H}_{0}: r=0$ & $21.05^{\star *}$ & $20.61^{\star *}$ & 15.49 & 14.26 \\
& At most 1 & $\mathrm{H}_{0}: r \leq 1$ & 0.44 & 0.44 & 3.84 & 3.84 \\
\hline \multirow{2}{*}{ LGDP/LREC } & None & $\mathrm{H}_{0}: r=0$ & $16.77^{\star *}$ & $12.80^{\star *}$ & 12.32 & 12.22 \\
& At most 1 & $\mathrm{H}_{0}: r \leq 1$ & 4.97 & 4.97 & 4.12 & 4.12 \\
\hline
\end{tabular}

Note: Lags interval (in first differences): 1 to $1 .{ }^{* *}$ denotes significant at $5 \%$ significance level. $\mathrm{r}$ denote the number of cointegrated vectors. 
Based on the Trace test statistic results and the Max-Eigen test statistic results (see Table 4), we notice that the null hypothesis of no cointegration relationship between the variables is rejected so the alternative hypothesis of at least 1 cointegration equation is accepted, at $5 \%$ significance level. As Granger (1981) and Engle and Granger (1987) state, if there is cointegration between two time series, there is a long-run effect that prevents the two time series from separating from each other.

In order to identify a possible long-run equilibrium between the variables number of ARIV, REC and GDP, we will apply the Johansen cointegration test. According to the results obtained from the Johansen-Juselius Cointegration Tests, we can decide the appropriateness of applying the vector error correction model (VECM). After normalizing the cointegrating vector to estimate the error correction model (ECM) of the dynamic structure we have (Andrei \& Bourbonnais, 2017):

$$
y_{t}=\alpha_{1}+\beta_{1} x_{t}+\varepsilon_{t}
$$

where: $y_{t}-$ is the endogenous variable, $x_{t}-$ is the exogenous variable, $\alpha_{1}, \beta_{1}$ - parameters, $\varepsilon_{t}$ - the random variable.

The error correction term can be derived from the previous equation:

$$
E C_{t}=y_{t}-\alpha_{1}-\beta_{1} x_{t}
$$

The equation becomes:

$$
\Delta y_{t}=a_{0}+\delta E C_{t-1}+\sum a_{1 j} \Delta y_{t-j}+\sum a_{2 j} \Delta x_{t-j}+u_{t} .
$$

In order to accomplish the system to converge to equilibrium, the adjustment coefficient should be negative in sign. A positive sign would implicate that the system diverges from the long-run equilibrium path (Greene, 2011).

\section{Results and discussion}

The presence of cointegration between variables indicates a long run relationship between them. Therefore, the vector error correction model (VECM) can be applied. The long run relationship between the number of international tourist arrivals (ARIV) and GDP per capita, respectively between international tourism receipts (REC) and GDP per capita for one cointegrating vector, for the case of Romania, is presented in Table 5.

The results show that the causal effect of the GDP on the ARIV and on the REC variable is significant in the long run, the estimated adjusted coefficients are statistically significant and relevant, as $\mathrm{p}$-values are less than 0.05 . The negative sign of this coefficients indicate that a long-run equilibrium characterizes the relationship between the mention variables. Therefore, the results confirm the first hypothesis (H1) of this study. On the other hand, with respect to the long-term causal effect of the ARIV and the REC variable on the GDP, we observe positive values which presuppose that the system deviates from the long-term equilibrium path. So, the long-term causal results show their divergence in the direction ARIV on the GDP, respectively the REC variable on the GDP. The short-run coefficients indicate convergence and significant results from GDP to the ARIV, from the REC to GDP and also from the ARIV to GDP. Regarding the short-term causal results of GDP on the REC, the short-term causal results indicate divergence and non-significant coefficients. 
Table 5. VECM and Granger causality tests (source: authors' estimates using Eviews 9)

\begin{tabular}{|c|c|c|c|c|}
\hline $\begin{array}{l}\text { Causality } \\
\text { direction }\end{array}$ & $\begin{array}{c}\text { Error correction term } \\
\text { (ECT) } \\
\text { [t-statistic }] \\
\text { (p-value) }\end{array}$ & $\begin{array}{l}\text { Short-run } \\
\text { Coefficient } \\
\text { [t-statistic] } \\
\text { (p-value) }\end{array}$ & $\begin{array}{l}\text { Lag coefficient } \\
\text { [t-statistic }] \\
\text { (p-value) }\end{array}$ & $\begin{array}{l}\text { F-statistic } \\
\text { (p-value) }\end{array}$ \\
\hline LARIV $\rightarrow$ LGDP & $\begin{array}{l}0.377509^{* * *} \\
{[2.60]} \\
(0.01)\end{array}$ & $\begin{array}{c}0.249224^{*} \\
{[1.78]} \\
(0.09)\end{array}$ & $\begin{array}{c}0.063983 \\
{[0.22]} \\
(0.82)\end{array}$ & $\begin{array}{c}3.533034^{\star *} \\
(0.03)\end{array}$ \\
\hline LGDP $\rightarrow$ LARIV & $\begin{array}{c}-1.53275^{\star * *} \\
{[-5.21]} \\
(0.00) \\
\end{array}$ & $\begin{array}{c}1.104846^{\star *} \\
{[2.23]} \\
(0.04) \\
\end{array}$ & $\begin{array}{c}0.808672^{\star * *} \\
{[3.37]} \\
(0.00) \\
\end{array}$ & $\begin{array}{c}9.441875^{\star * *} \\
(0.00)\end{array}$ \\
\hline LREC $\rightarrow$ LGDP & $\begin{array}{c}0.249019^{\star *} \\
{[2.32]} \\
(0.03)\end{array}$ & $\begin{array}{c}0.095192^{\star *} \\
{[2.21]} \\
(0.04)\end{array}$ & $\begin{array}{c}0.033991 \\
{[0.13]} \\
(0.89)\end{array}$ & $\begin{array}{c}3.769604^{* *} \\
(0.03)\end{array}$ \\
\hline LGDP $\rightarrow$ LREC & $\begin{array}{c}-0.713792^{* * *} \\
{[-3.10]} \\
(0.00)\end{array}$ & $\begin{array}{c}0.606842 \\
{[0.39]} \\
(0.69)\end{array}$ & $\begin{array}{c}0.341433 \\
{[1.34]} \\
(0.19)\end{array}$ & $\begin{array}{c}4.573808^{\star * *} \\
\quad(0.01)\end{array}$ \\
\hline
\end{tabular}

Note: ${ }^{*}, * * * *$ denotes significant at $10 \%, 5 \%$ and $1 \%$ significance level.

We check also the quality of the residue, namely: the normal distribution, the autocorrelation and the homoscedasticity. Thus, in the Table 6, below, we presented the probabilities of the tests associated with the three hypotheses on errors listed above.

Table 6. The p-values of residual tests (source: authors' estimates using Eviews 9)

\begin{tabular}{|l|c|c|c|}
\hline $\begin{array}{c}\text { Models based on causality } \\
\text { direction }\end{array}$ & $\begin{array}{c}\mathrm{H}_{0}-\text { the errors are } \\
\text { homoscedastic } \\
\text { (ARCH LM) }\end{array}$ & $\begin{array}{c}\mathrm{H}_{0} \text { - the errors are } \\
\text { independent } \\
\text { (Breusch Godfrey LM) }\end{array}$ & $\begin{array}{c}\mathrm{H}_{0} \text { - the errors are } \\
\text { normally distributed } \\
\text { (Jarque-Bera) }\end{array}$ \\
\hline LARIV $\rightarrow$ LGDP & 0.6947 & 0.4139 & 0.3279 \\
\hline LGDP $\rightarrow$ LARIV & 0.8604 & 0.4157 & 0.9717 \\
\hline LREC $\rightarrow$ LGDP & 0.1658 & 0.3485 & 0.1585 \\
\hline LGDP $\rightarrow$ LREC & 0.7501 & 0.3769 & 0.9186 \\
\hline
\end{tabular}

Given that the values of these probabilities are higher than the $5 \%$ threshold ( $\mathrm{p}$-value = 0.05), then the null hypothesis is accepted as valid, which validates the correct representation of the residue of the estimated models. According to the results presented in Table 6, we can affirm that the null hypothesis is accepted for all these three residual tests (ARCH LM, Breusch Godfrey LM Test and Jarque Bera), therefore, the correct representation of the residue of the estimated models is validated.

The results of the cointegration test show the existence of a long-run, stable equilibrium between Romania's international tourism and economic growth. The existence of long-run relationships between the development of international tourism in Romania and economic growth means that both variables, i.e. GDP and international tourism (ARIV and REC), are causally related at least in one direction. To find out the causality, we apply the Granger causality test. The long-run Granger causality from the independent variables to the dependent variable and the one-way short-term Granger causality are presented in the bellow Figure 1. 


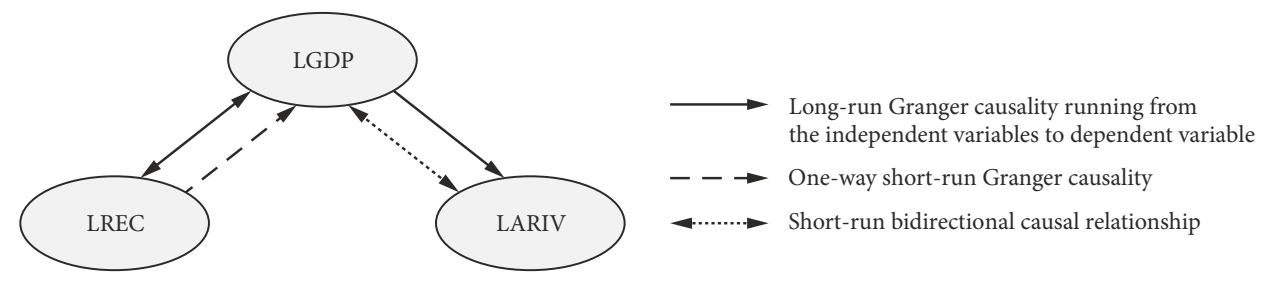

Figure 1. Granger causality relationship between GDP, ARIV and REC (source: authors' contribution)

The results indicate the existence of a long-term unidirectional Granger causality between the development of tourism and economic growth. Thus, Romania's economic growth is the cause of Granger's development of Romanian tourism, i.e. national economic growth can promote the long-term development of international touristic flows and receipts. However, the existence of the converse (the long-run influence of tourism on economic growth) is doubtful. In the short-run, we identify a unidirectional causal relationship from REC to GDP. We also find evidence of a short-term bidirectional causal relationship between the GDP and the number of international tourist arrivals (ARIV). The results confirm the third hypothesis (H3) but only in case of the GDP and ARIV.

\section{Conclusions}

This paper aims at analysing the long-run and short-run relationship between GDP and international tourist arrivals (ARIV), respectively international tourism receipts (REC) over the period 1995-2016 in Romania, using the Johansen cointegration test and Granger causality. The results show that the causal effect of the GDP on the ARIV and on the REC variable is significant in the long run and the sign of this adjustment coefficients is negative. So, the long-term causal results show their convergence in the following direction: GDP to the ARIV and GDP to the REC. As regard to the long-term causal effect of the ARIV and the REC variable on the GDP, the sign of this adjustment coefficients is positive, which presuppose that the system deviates from the long-term equilibrium path. We also study the short-run relationship between the variables. The results show that in the short-run, the causal effect of the GDP to the ARIV, of the REC to GDP and also of the ARIV to GDP, is significant. The short-term causal results of GDP on the international tourism receipts indicate divergence and non-significant coefficients.

In other words, our study highlights that, in the case of Romania, the second (i.e. growth-led tourism - GLTH) hypothesis is confirmed on the long run (with respect to both international tourism receipt, and international tourism arrivals). On the other hand, on a short term, the tourism-led growth hypothesis (TLGH) is supported for the relationship between GDP and international tourism receipt, whereas the bidirectional causality hypothesis (BC) describes the relationship between GDP and international tourism arrivals. In terms of policy recommendations, Romania is a country wherein the ability of the tourism industry to attract tourists and international revenue (thus leading to the growth of this sector in particular, and of the economy in general) is potential rather than actual. Henceforth, on a 
short term, it is recommended to support the tourism industry (in accordance with TLGH and $\mathrm{BC}$ ), thus supporting GDP growth. This is followed by a consistent growth of GDP, leading to long-term returns for the tourism industry (according to GLTH). For as long as sustainability is taken into account in economic development, it is expected that, in the long run, sustainable practices and their benefits become commonplace in the tourism sector as well (Mester et al., 2016).

We consider that our paper only partly confirms similar studies, which determines us to continue our research on the subject in the future, by taking into account more economic variables and influences, as well as, if possible, longer analysis timeframes. Ultimately, the most important limitation of our study is the relative short length of the time series used (which is also encountered in other analyses), since the earliest available data for the tourism indicators in Romania stem from 1995.

\section{Funding}

No grants were used for the research and publication of this article.

\section{Author contributions}

The paper is a result of a collaborative work. AB, DB and RS conceived the study, $\mathrm{AB}$ and $\mathrm{DB}$ reviewed the literature, $\mathrm{DB}, \mathrm{RS}$ and $\mathrm{SD}$ did the data analysis. $\mathrm{AB}, \mathrm{DB}$ and $\mathrm{RS}$ wrote the first draft. All authors revised the paper and prepared the final article.

\section{Disclosure statement}

Authors declare they have no competing financial, professional, or personal interests from other parties.

\section{References}

Akinboade, O., \& Braimoh, L. (2010). International tourism and economic development in South Africa: A granger causality test. International Journal of Tourism Research, 12(2), 149-163. https://doi.org/10.1002/jtr.743

Andrei, T., \& Bourbonnais, R. (2017). Econometrie. Editia a doua revazuta si adaugata. Economica.

Apergis, N., \& Payne, J. (2012). Research note: Tourism and growth in the Caribbean-evidence from a panel error correction model. Tourism Economics, 18(2), 449-456 https://doi.org/10.5367/te.2012.0119

Arezki, R., Cherif, R., \& Piotrowski, J. (2009). Tourism specialization and economic development: Evidence from the UNESCO World Heritage List (IMF WP/09/176). IMF Institute and Fiscal Affairs Department. https://doi.org/10.5089/9781451873238.001

Arslanturk, Y., \& Atan, S. (2012). Dynamic relation between economic growth, foreign exchange and tourism incomes: an econometric perspective on Turkey. Journal of Business Economics \& Finance, $1(1), 30-37$. 
Bac, D. P., \& Aksoz, E. O. (2017). Contemporary challenges for sustainable tourism - a regional perspective. Oradea Journal of Business and Economics, 2(2), 37-44.

Badulescu, A., Simut, R., \& Badulescu, D. (2018). The complex relationship between international tourism demand and economic growth: an analysis on Central and Eastern European economies. Amfiteatru Economic, 20(Special No. 12), 935-950. https://doi.org/10.24818/EA/2018/S12/935

Balaguer, J., \& Cantavella-Jorda, M. (2002). Tourism as a long-run economic growth factor: the Spanish case. Applied Economics, 34(7), 877-884. https://doi.org/10.1080/00036840110058923

Bayramoğlu, T., \& Arı, I. (2015). The relationship between tourism and economic growth in Greece economy: a time series analysis. Computational Methods in Social Sciences, 3(1), 89-93.

Bento, J. (2016). Tourism and economic growth in Portugal: an empirical investigation of causal links. Tourism \& Management Studies, 12(1), 164-171. https://doi.org/10.18089/tms.2016.12117

Biji, E., Lilea, E., Vătui, M., \& Roşca, E. (2015). Statistical analysis of the regional tourism development in the European Union. The USV Annals of Economics and Public Administration, 15(2(22)), 189-199.

Brida, J., Monterubbianesi, P., \& Zapata-Aguirre, S. (2011). The impacts of tourism on economic growth and development: the case of the main Colombian destinations. PASOS: Revista de Turismo y Patrimonio Cultural, 9(2), 291-303.

Brida, J., Risso, W., \& Bonapace, A. (2008, May 7-9). The contribution of tourism to economic growth: an empirical analysis for the case of Chile.In Sustainable Tourism as a Factor of Local Development, Monza, Italy. GRISS - Research Unit on Sustainable Development, University of Milano, Bicocca. http://ssrn.com/abstract=1298404

Caglayan, E., Sak, N., \& Karymshakov, K. (2012). Relationship between tourism and economic growth: A panel granger causality approach. Asian Economic and Financial Review, 2(5), 518-529.

Cárdenas-García, P., Sánchez-Rivero, M., \& Pulido-Fernández, J. (2015). Does tourism growth influence economic development?. Journal of Travel Research, 54(2), 206-221. https://doi.org/10.1177/0047287513514297

Chou, M. (2013). Does tourism development promote economic growth in transition countries? A panel data analysis. Economic Modelling, 33, 226-232. https://doi.org/10.1016/j.econmod.2013.04.024

Cortés-Jiménez, I., Pulina, M., Riera i Prunera, C., \& Artis, M. (2009). Tourism and Exports as a means of Growth (IREA Working Papers 200910). University of Barcelona, Research Institute of Applied Economics.

Demiroz, D., \& Ongan, S. (2005). The contribution of tourism to the long-run Turkish Economic Growth. Ekonomický časopis (Journal of Economics), 53(9), 880-894.

Dickey, D., \& Fuller, W. (1979). Distribution of the estimators for autoregressive time series with a unit root. Journal of the American Statistical Association, 74(366), 427-431. https://doi.org/10.2307/2286348

Dogru, T., \& Bulut, U. (2018). Is tourism an engine for economic recovery? Theory and empirical evidence. Tourism Management, 67, 425-434. https://doi.org/10.1016/j.tourman.2017.06.014

Dritsakis, N. (2004). Tourism as a long-run economic growth factor: An empirical investigation for Greece using causality analysis. Tourism Economics, 10(3), 305-316. https://doi.org/10.5367/0000000041895094

Durbarry, R. (2004). Tourism and economic growth: The case of Mauritius. Tourism Economics, 10(4), 389-401. https://doi.org/10.5367/0000000042430962

Eeckels, B. (2012). Tourism income and economic growth in Greece: empirical evidence from their cyclical components. Tourism Economics, 18(4), 817-834. https://doi.org/10.5367/te.2012.0148

Enders, W. (2014). Applied econometric time series (4 ed.). Wiley. 
Engle, R., \&, Granger, C. (1987). Co-integration and error correction: representation, estimation and testing. Econometrica, 55(2), 251-276. https://doi.org/10.2307/1913236

Fahimi, A., Akadiri, S., Seraj, M., \& Akadiri, A. (2018). Testing the role of tourism and human capital development in economic growth. A panel causality study of micro states. Tourism Management Perspectives, 28, 62-70. https://doi.org/10.1016/j.tmp.2018.08.004

Granger, C. (1981). Some properties of time series data and their use in econometric model specification. Journal of Econometrics, 16, 121-130. https://doi.org/10.1016/0304-4076(81)90079-8

Greene, W. H. (2011). Econométrie (7 ed.). Pearson Education France.

Gwenhure, Y., \& Odhiambo, N. (2017). Tourism and economic growth: A review of international literature. Tourism: An International Interdisciplinary Journal, 65(1), 33-44.

Hye, Q., \& Khan, R. (2013). Tourism-led Growth hypothesis: a case study of Pakistan. Asia Pacific Journal of Tourism Research, 18(4), 303-313. https://doi.org/10.1080/10941665.2012.658412

Jalil, A., Mahmood, T., \& Idrees, M. (2013). Tourism-Growth nexus in Pakistan: Evidence from ARDL bounds tests. Economic Modelling, 35(C), 185-191. https://doi.org/10.1016/j.econmod.2013.06.034

Johansen, S. (1988). Statistical analysis of cointegrating vectors. Journal of Economic Dynamics and Control, 12, 231-254. https://doi.org/10.1016/0165-1889(88)90041-3

Johansen, S. (1991). Estimation and hypothesis testing of cointegration vectors in gaussian vector autoregressive models. Econometrica, 59(6), 1551-1580. https://doi.org/10.2307/2938278

Johansen, S., \& Juselius, K. (1990). Maximum likelihood estimation and inference on cointegration with application to the demand for money. Oxford Bulletin of Economics and Statistics, 52, 169-210. https://doi.org/10.1111/j.1468-0084.1990.mp52002003.x

Kasimati, E. (2011). Economic impact of tourism on Greece's economy: Cointegration and causality analysis. International Research Journal of Finance and Economics, 79, 79-85.

Katircioglu, S. (2009a). Tourism, trade and growth: The case of Cyprus. Applied Economics, 41(21), 2741-2750. https://doi.org/10.1080/00036840701335512

Katircioglu, S. (2009b). Revising the tourism-led-growth hypothesis for Turkey using the bounds test and Johansen approach for cointegration. Tourism Management, 30(1), 17-20. https://doi.org/10.1016/j.tourman.2008.04.004

Kibara, O., Odhiambo, N., \& Njuguna, J. (2012). Tourism and economic growth in Kenya: An empirical investigation. International Business \& Economics Research Journal (IBER), 11(5), 517-528. https://doi.org/10.19030/iber.v11i5.6970

Kim, H., Chen, M., \& Jang, S. (2006). Tourism expansion and economic development: The case of Taiwan. Tourism Management, 27(5), 925-933. https://doi.org/10.1016/j.tourman.2005.05.011

Lanza, A., \& Pigliaru, F. (2000). Why are tourism countries small and fast-growing?. In A. Fossati \& G. Panella, (Eds.), Tourism and sustainable economic development (pp. 57-69). Kluwer Academic Publishers. https://doi.org/10.1007/978-1-4615-4321-3_3

Lee, C. C., \& Chang, C. P. (2008). Tourism development and economic growth: A closer look at panels. Tourism Management, 29(1), 180-192. https://doi.org/10.1016/j.tourman.2007.02.013

Lee, C. C., \& Chien, M. S. (2008). Structural breaks, tourism development, and economic growth: Evidence from Taiwan. Mathematics and Computers in Simulation, 77(4), 358-368. https://doi.org/10.1016/j.matcom.2007.03.004

MacKinnon, J. G., Haug, A. A., \& Michelis, L. (1999). Numerical distribution functions of likelihood ratio tests for cointegration. Journal of Applied Econometrics, 14, 563-577. https://doi.org/10.1002/(SICI)1099-1255(199909/10)14:5<563::AID-JAE530>3.0.CO;2-R

Martins, L., Gan, Y., \& Ferreira-Lopes, A. (2017). An empirical analysis of the influence of macroeconomic determinants on world tourism demand. Tourism Management, 61, 248-260.

https://doi.org/10.1016/j.tourman.2017.01.008 
Mathieson, A., \& Wall, G. (1982). Tourism: Economic, physical, and social impacts. Longman.

Mazilu, M., Dumitrescu, D., Marinescu, R., \& Baltălungă, A. (2018). New trends in Romanian tourism in 2018. Journal of Tourism \& Hospitality, 7(4), 1-6. https://doi.org/10.4172/2167-0269.1000372

Mester, I., Badulescu, D., Badulescu, A., Bac, D .P., Simut, R., \& Sehleanu, M. (2016). Attitudes and practices concerning sustainability. A research case on Romanian tourism ventures. Journal of Environmental Protection and Ecology, 17(2), 687-695.

Mishra, P., Rout, H., \& Mohapatra, S. (2011). Causality between tourism and economic growth: Empirical evidence from India. European Journal of Social Sciences, 18(4), 518-527. https://doi.org/10.1353/jda.2017.0037

Oh, C. O. (2005). The contribution of tourism development to economic growth in the Korean economy. Tourism Management, 26(1), 39-44. https://doi.org/10.1016/j.tourman.2003.09.014

Ozturk, I., \& Acaravci, A. (2009). On the causality between tourism growth and economic growth: Empirical evidence from Turkey. Transylvanian Review of Administrative Sciences, 25(E), 73-81.

Payne, J., \& Mervar, A. (2010). Research note: The tourism-growth nexus in Croatia. Tourism Economics, 16(4), 1089-1094. https://doi.org/10.5367/te.2010.0014

Postelnicu, C., \& Dabija, D. C. (2018). Romanian tourism: Past, Present and future in the context of globalization. Ecoforum, 7(1(14)).

Rivera, M. A. (2017). The synergies between human development, economic growth, and tourism within a developing country: An empirical model for Ecuador. Journal of Destination Marketing \& Management, 6(3), 221-232. https://doi.org/10.1016/j.jdmm.2016.04.002

Sanchez Carrera, E., Risso, W., \& Brida, J. (2008). Tourism's Impact on long-run Mexican economic growth. Economics Bulletin, 3(21), 1-8. https://doi.org/10.2139/ssrn.1076225

Sánchez-Rivero, M., Pulido-Fernández, J., \& Cárdenas-García, P. (2013). Tourism growth versus economic development: An analysis by multivariate techniques. In A. Matías (Ed.), Quantitative methods in tourism economics (pp. 235-251). Physica Verlag.

https://doi.org/10.1007/978-3-7908-2879-5_13

Schubert, S., Brida, J., \& Risso, W. (2011). The impacts of international tourism demand on economic growth of small economies dependent on tourism. Tourism Management, 32, 377-385. https://doi.org/10.1016/j.tourman.2010.03.007

Sehleanu, M. (2019). Analysis of foreign participation in the share capital of companies from the counties of North-West region of Romania. Oradea Journal of Business and Economics, 4(1), 7-16.

Sequeira, T., \& Nunes, P. (2008). Does tourism influence economic growth? A dynamic panel data approach. Applied Economics, 40(18), 2431-2441. https://doi.org/10.1080/00036840600949520

Škrabić Perić, B., \& Vidović, Ž. (2017). Heterogeneous panel granger causality between GDP and tourism in $11 \mathrm{EU}$ members in Central and Southeastern Europe. Eastern European Business and Economics Journal, 3(1), 6-27.

Surugiu, C., Frent, C., \& Surugiu, M. (2009). Tourism and its impact upon the Romanian economy: An input-output approach. Analele Stiintifice ale Universitatii "Alexandru Ioan Cuza” din Iasi, Stiinte Economice, LVI, 355-376.

Surugiu, C., \& Surugiu, M.-R. (2013). Is the tourism sector supportive of economic growth? Empirical evidence on Romanian tourism. Tourism Economics, 19(1), 115-132.

https://doi.org/10.5367/te.2013.0196

Surugiu, C., \& Surugiu, M. R. (2015). Tourism as backer for regional development. A real deal or just another hope?. EuroEconomica, 34(1).

Tang, C., \& Jang, S. (2009). The tourism-economy causality in the United States: A sub-industry level examination. Tourism Management, 30(4), 553-558. https://doi.org/10.1016/j.tourman.2008.09.009 
Tang, C., \& Tan, E. (2015). Does tourism effectively stimulate Malaysia's economic growth?. Tourism Management, 46, 158-163. https://doi.org/10.1016/j.tourman.2014.06.020

Tugcu, C. (2014). Tourism and economic growth nexus revisited: A panel causality analysis for the case of the Mediterranean region. Tourism Management, 42(C), 207-212. https://doi.org/10.1016/j.tourman.2013.12.007

The World Bank. (2017). World Development Indicators, 1995-2016. Retrieved February 10, 2018, from http://databank.worldbank.org/data/indicator/NY.GDP.MKTP.KD.ZG/1ff4a498/Popular-Indicators

Watkins, M., Ziyadin, S., Imatayeva, A., Kurmangalieva, A., Blembayeva, A. (2018), Digital tourism as a key factor in the development of the economy, Economic Annals-XXI, 169(1-2), 40-45. https://doi.org/10.21003/ea.V169-08

World Tourism Organization. (2018). UNWTO Annual Report 2017. UNWTO, Madrid.

World Travel \& Tourism Council. (2012). The comparative economic impact of travel \& tourism. London.

World Travel \& Tourism Council. (2018). Travel \& tourism economic impact 2018. Romania. London.

World Travel \& Tourism Council. (2019). WTTC Economic Impact Research 2019. Retrieved May 06, 2019, from https://www.wttc.org/

Zaman, G., Vasile, V., Surugiu, M. R., \& Surugiu, C. (2010). Tourism and economic development in Romania: input-output analysis perspective. Romanian Journal of Economics, 32(2(40)), 5-37. 